\title{
Fast Identification of Korean Cattle Based on Simultaneous Detection of Various Single Nucleotide Polymorphisms Markers by Capillary Electrophoresis
}

\author{
Hyeah Go, Miji Lee, Doori Oh, Kwan-Suk Kim, ${ }^{\dagger}$ Keunchang Cho, ${ }^{\ddagger}$ Dong Jin Yoo, ${ }^{\S}$ and Seong Ho Kang \\ Department of Chemistrv and Research Institute of Phisics and Chemistry (RINPAC), Chonbuk National University, \\ Jeonju 561-756, Korea. ${ }^{*}$ E-mail: shkangachonbukac.kr \\ 'Deparment of Animal Science. Chungbuk Vational Lniversitw, Chungbuk 361-763. Korea \\ -Doosan I enture Digm 126-1, Pyongchon, Dongan, Anvang, Gleonggi +31-070, Korea \\ Separtment of Chemistri, Seonam Lniversitw, Namuon $590-711$. Korea \\ Received April t, 2009, Accepted July 16, 2009
}

Key Words: Korean cattle. Capillary electrophoresis. Single nucleotide polymorphism (SNP). Fast identification. Simultaneous detection

Due to the establishment of the free trade agreement (FTA) and the various changes that have occurred in international trade. fast and accurate identification methods for the speciesspecific genes of various cattle are increasingly needed. Most cattle breeds have a specific coat color pattem that distinguishes them. Korean cattle called Hanwoo also have a unique coat color ranging from yellowish brown to dark brown, including a red coat color. which allows them to be distinguished. ${ }^{1 .}$ However. processed meat derived from Hanwoo cannot easily be identified in this way. Therefore. the development of fast and accurate analytical methods of identifying the speciesspecific genes of various cattle based on a combination of scientific analysis and the field inspection of the unique coat color and shape is increasingly needed.

The Melanocortin-1-receptor (MCIR) gene encodes a protein with key regulatory functions in the synthesis of melanin. ${ }^{3}$ The MCIR associated with the coat color information is located in the melanocytes on the extension locus of chromosome 18. The MCIR gene has two types of mutations, in which either the $C$ base is substituted for the T base in the $296^{\text {th }}$ open reading frame (ORF) or the G base is deleted in the $310^{\text {th }} \mathrm{ORF}{ }^{4.5}$ Based on gene analysis. these mutations can distinguish Korean cattle and non-Korean cattle according to their coat colors.

In this study. a simple allele-specific polymerase chain reaction (AS-PCR) was co-amplified for various different specific DNA fragments of Hanwoo AS-PCR primers (i.e. MC IR $310 \mathrm{G} \mathrm{del,}$ MC1R 296Y SNP. LM215-1.2 C and LM215-1.2 D). The amplified AS-PCR products have conventionally been detected by electrophoresis on agarose gels. ${ }^{6}$ Even though traditional slab gel electrophoresis enables parallel analysis. its throughput is limited by the slow speed of electrophoresis. approximately $\mathrm{l}-2 \mathrm{~h}$ for a single nin. Moreover. the sample and reagents. such as the agarose gel, are largely consumed in the process. Guttman et $a$. used ultra-thin-layer agarose gel electrophoresis in an attempt to overcome these weak points. However. their method still has the disadvantages of low sensitivity and inaccurate detection of the PCR product size. Based on voltage programming. the four different specific single nucleotide polymorphism (SNP) markers of Korean cattle were simultaneously determined by capillary electrophoresis (CE) for fast and accurate identification. The $\mathrm{CE}$ with laser-induced fluorescence detection (LIF) system has the advantages of a short analy'sis time and snall santele volume $(<\mathrm{nL}){ }^{8.10}$ Furthermore. the high voltage applied in the capillary causes the heat to effectively diffuse outside of it. because the ratio of the surface area to the volume is very large. Although too high voltage causes Joule heating. which lowers the reproducibility and decomposes the biosamples, the voltage programming method can efficiently reduce the Joule heating and analy sis time. .11-14 $^{\text {. }}$

The eighteen genonuic DNA samples (nine Korean cattle and nine non-Korean cattle samples) obtained from Chungbuk National University were amplified using the designed primers (The Solgent Co.. Ltd., MC1R $310 \mathrm{G}$ del. MC1R 296Y SNP, LM2 15-1.2 C and LM2 15-1.2 D) for the AS-PCR of Hanwoo. which showed DNA products with various lengths, viz. 165 . $170.207 .225 .240 .308,422$ and $647 \mathrm{bp}$ (Table 1). The developed AS-PCR primers are formed with mutant DNA sequences to identify the SNPs of the specific cattle breeds by PCR. The $\mathrm{MClR}$ gene has a mutation which converts leucine into proline. This conversion of the amino acid is due to the replacentent of the $\mathrm{T}$ base $\left(\mathrm{E}^{\mathrm{D}}\right)$ with the $\mathrm{C}$ base $\left(\mathrm{E}^{-}\right)$at the $296^{\text {th }} \mathrm{ORF}$. The other mutation has a frame slift which is caused by the deletion of the $\mathrm{G}$ base at the $310^{\mathrm{d}} \mathrm{ORF}{ }^{4.5}$ At the extension locus, three major alleles were previously reported $\left(\mathrm{E}^{\mathrm{D}}\right.$ : doninaut. doninant black; $E^{+}$; intermediate. recessive black; e: recessive. red). ${ }^{15}$ In this study. Korean cattle having a yellowish brown color were confirmed to have gene frequencies of $\mathrm{E}^{+} / \mathrm{e}(0.05)$ and e/e $(0.95){ }^{15.16}$ which showed different values to other cattle breeds. "On the basis of this finding. primers were designed for the Korean cattle and non-Korean cattle.

We separated the standard 100-bp DNA ladder between $100 \mathrm{bp}$ and $700 \mathrm{bp}$. because the amplified AS-PCR products have specific ranges of DNA lengths. viz. 165, 170.207. 225. $240.308 .+22$ and $647 \mathrm{bp}$ (Table 1). In general. increasing the voltage increases the electroosmotic flow (EOF) and reduces the nugration times. leading to shorter analysis times and increasing the efficiency of resolution. ${ }^{18,19}$ However, higher voltages lead to higher currents and increased Joule heating that may lead to broader peaks. non-reproducible migration times, sample decomposition or denaturation. ${ }^{18}$ Figure 1 shows the electropherogranis obtained using the low constant field strength (LCFS), high constant field strength (HCFS) and voltage pro- 
Table 1. Characteristics of Korean cattle (Hanwoo) and non-Korean cattle SNP marker primers used for allele-specific PCR

\begin{tabular}{|c|c|c|}
\hline SNP marker & Product size (bp) & Primer sequence \\
\hline MC1R $310 \mathrm{G}$ del & $\begin{array}{l}\mathrm{K}^{2}=170,308 \\
\mathrm{NK}^{b}=207,308\end{array}$ & 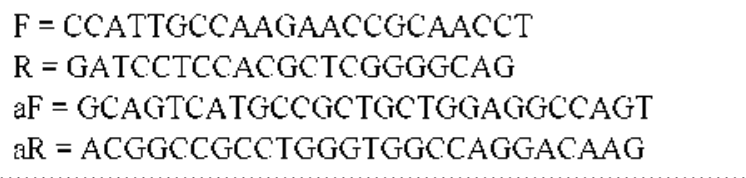 \\
\hline MCIR 296Y SNP & $\begin{array}{l}\mathrm{K}^{2}=225,308 \\
\mathrm{NK}^{b}=165,308\end{array}$ & 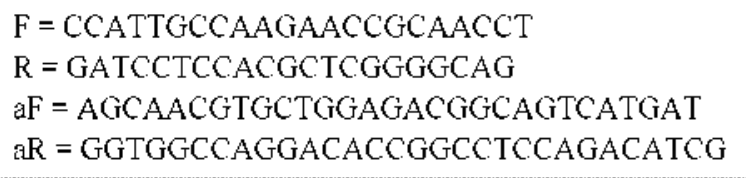 \\
\hline LM2 $15-1,2 \mathrm{C}$ & $\begin{array}{l}\mathrm{K}^{u}=\mathrm{No}^{*} \\
\mathrm{NK}^{b}=422,647\end{array}$ & $\begin{array}{l}\text { LM215-1 F = AGAAGATGTGGGTTCAATCACC } \\
\text { LM2 15-1 R = CTCTTCCGGACACTGGGCTCTT } \\
\text { LM215-2 F = GATGTGGGTTCAATCCCYGTGCC } \\
\text { LM215-2 R = GCTTCAGCCTTTACTCTGTGAACC }\end{array}$ \\
\hline LM215-1,2 D & $\begin{array}{l}\mathrm{K}^{a}=240,647 \\
\mathrm{NK}^{b}=\mathrm{No}^{*}\end{array}$ & $\begin{array}{l}\text { LM2 15-1 F = CTATAGAAGATGTGGGTTCAATCACT } \\
\text { LM215-1 R = TCCACACAATTCTTACCTGGTGG } \\
\text { LM215-2 F = GATGTGGGTTCAATCCCYGTGCT } \\
\text { LM215-2 R = GCTTCAGCCTTTACTCTGTGAACC }\end{array}$ \\
\hline
\end{tabular}

${ }^{\prime} \mathrm{K}=$ Korean cattle $($ Hanwoo). $\mathrm{NK}=$ non-Korean cattle. $\mathrm{F}=$ Forward primer, $\mathrm{R}=$ Reierse primer, $\mathrm{aF}=$ Allele forward primer, aR $=\mathrm{Allele}$ reverse primer. "No indicates no detection in CE-LIF.

gramming methods with respect to the migration time and resolution of the selected DNAs. Figure IA demonstrates that the DNAs up to the 700 bp DNA were completely separated after 7.0 min using LCFS. Figure $1 B$ show's that when HCFS was used a short migration time of 2.1 min was obtained but

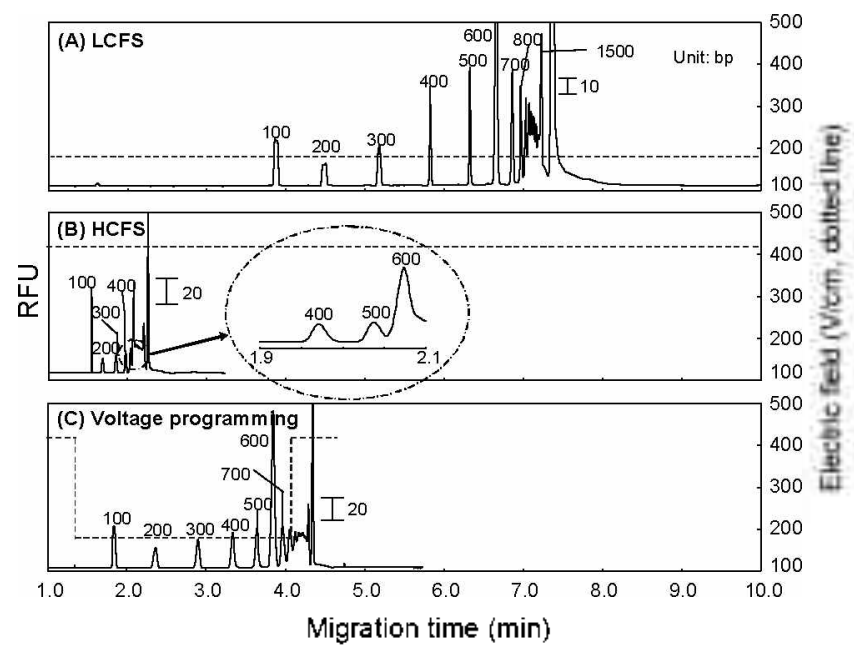

Figure 1. Comparisons of CE-LIF electropherograms for the $100-\mathrm{bp}$ DNA ladder obtained using (A) LCFS, (B) HCHS, and (C) voltage programming. CE separation condition: Capillary, $75 \mu \mathrm{m}$ I.D. fusedsilica capillary; total length, $25 \mathrm{~cm}$, effective length, $10 \mathrm{~cm}$, excitation source, $5 \mathrm{~mW}$ He-Ne laser ( $543 \mathrm{~nm}$ ), running bufter, $0.5 \mathrm{ppm} \mathrm{EtBr}$ in $1 \times$ TBE buffer ( $\mathrm{pH} 8.45$ ) coating gel, $1.0 \% \mathrm{PVP}(\Lambda, 1,000,000)$; sieving matrix, $0.8 \%$ PEO $\left(M \mu_{\mathrm{T}} 8,000,000\right) .100-\mathrm{bp}$ DNA ladder (Invitrogen) concentration, $25 \mathrm{ng} / \mu \mathrm{L}$. Sample injection, electrokinetic injection at electric field strength of $120 \mathrm{~V} / \mathrm{cm}$ for $10 \mathrm{~s}$. Sample separation electric field: LCFS $-180 \mathrm{~V} / \mathrm{cm}$. HCFS $=420 \mathrm{~V} / \mathrm{cm}$. Voltage programming $=420 \mathrm{~V} / \mathrm{cm}$ for $1.3 \mathrm{~min}, 180 \mathrm{~V} / \mathrm{cm}$ for $2.9 \mathrm{~min}$ and 420 V/cm for $0.5 \mathrm{~min}$. Indications: LCFS, low constant field strength: HCFS, ligh constant field strength. The blue dotted line represents the applied electric field. RFU = relative fluorescence unit. that not all of the DNAs up to 700 bp were completely separated. So. we attempted to find the optimum voltage programming condition for the baseline separation of all specific DNAs (i.e. $100-700 \mathrm{bp}$ ) in the $100-\mathrm{bp}$ DNA ladder as follows: Before the first peak ( $100 \mathrm{bp}$ DNA) appeared, we applied an HCFS of $420 \mathrm{~V} / \mathrm{cm}$ to reduce the separation time to $1.3 \mathrm{~min}$. Then. we applied an LCFS of $180 \mathrm{~V} / \mathrm{cm}$ for $2.9 \mathrm{~min}$ for the base separation of the $100-700 \mathrm{bp}$ DNAs. After the separation of the 700 bp DNA. the electric field strength was increased again to 420 $\mathrm{V} / \mathrm{cm}$ for fast separation. Figure $\mathrm{IC}$ indicates that all of the DNAs up to 700 bp were separated after 4.0 min using voltage programming. which was 3 min faster than LCFS. The DNAs over 800 bp exlubited poor resolution, but these resolutions were not important in this study, because the AS-PCR products of the SNP markers of Korean cattle have specific and distinct lengths within the range of $100-700 \mathrm{bp}$ (Table 1 ).

When the nine Korean cattle samples were amplified using AS-PCR. the MC1R $310 \mathrm{G}$ del appeared at 170 and $308 \mathrm{bp}$, the MCIR 296Y SNP appeared at 225 and 308 bp. LM2 15-1.2 C gave no peak and LM215-1,2 D appeared at 240 and $647 \mathrm{bp}$. When the nine non-Korean cattle were amplified. the MCIR $310 \mathrm{G}$ del appeared at 207 and 308 bp. the MCIR 296Y SNP appeared at 165 and 308 bp. LM215-1,2 C appeared at 422 and $647 \mathrm{bp}$ and LM215-1.2 D gave no peak. Figure 2 shows that all of the AS-PCR products with different DNA lengths (i.e. $165-647 \mathrm{bp}$ ) appeared in the electropherograms within 4 min under the optimum voltage programming conditions as follows: $420 \mathrm{~V} / \mathrm{cm}$ for $1.3 \mathrm{~min} .180 \mathrm{~V} / \mathrm{cm}$ for $2.9 \mathrm{~min}$ and 420 $\mathrm{V} / \mathrm{cm}$ for $0.5 \mathrm{~min}$. The PCR products of Hanwoo were analyzed at least $15-30$ times faster than that achieved using the conventional slab gel electrophoresis method. After the successful detection of the Korean and non-Korean cattle samples under the optimum separation conditions. the CE results showed $100 \%$ correlation for the cattle samples. Excellent reproducibility 


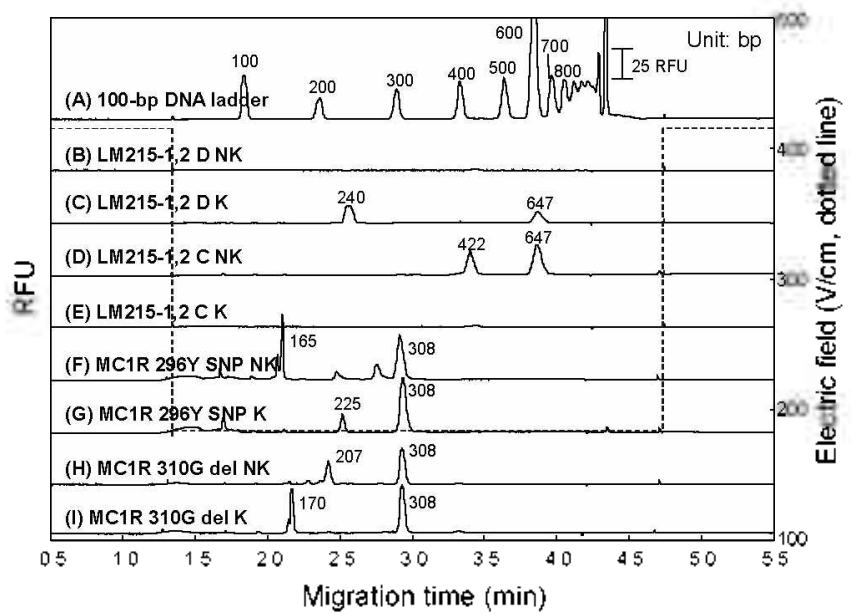

Figure 2. Representative electropherograms based on the voltage programming by CE-LIF of the various Korean cattle and non-Korean cattle SNP markers under the optimum separation conditions. CE separation conditions: sample separation electric field, $420 \mathrm{~V} / \mathrm{cm}$ for $1.3 \mathrm{~min}, 180 \mathrm{~V} / \mathrm{cm}$ for $2.9 \mathrm{~min}$ and $420 \mathrm{~V} / \mathrm{cm}$ for $0.5 \mathrm{~min}$. Indications: (A) $=$ Standard $100-b p$ DNA ladder $(B)=L M 215-1,2$ D non-Korean cattle. (C) = LM2 15-1,2 D Korean cattle. (D) $=$ LM2 15- 1.2 C nonKorean cattle. $(\mathrm{E})=\mathrm{LM} 215-1,2 \mathrm{C}$ Korean cattle $(\mathrm{F})=\mathrm{MClR} 296 \mathrm{Y}$ SNP non-Korean cattle $(\mathrm{G})=$ MC1R $296 \mathrm{Y}$ SNP Korean cattle $(\mathrm{H})=$ MC 1 R $310 \mathrm{G}$ del non-Korean cattle. (I) = MC 1 R $310 \mathrm{G}$ del Korean cattle. The other $\mathrm{CE}$ conditions are the same as those shown in Figure 1 .

Table 2. The migration times and resolutions of the SNP markers of the Korean cattle (Hanwoo) and non-Korean cattle under optinnun conditions based on voltage programming by $\mathrm{CE}$

\begin{tabular}{|c|c|c|c|}
\hline SNP marker & $\begin{array}{l}\text { Length } \\
\text { (bp) }\end{array}$ & $\begin{array}{l}\text { Migration time } \\
(\mathrm{min})^{\prime \prime}\end{array}$ & $R_{i}^{b}$ \\
\hline \multirow{2}{*}{$\begin{array}{l}\text { MCIR } 310 \mathrm{G} \text { del } \\
\text { Korean cattle }\end{array}$} & 170 & $2.19 \pm 0.02$ & \multirow{2}{*}{$4.19 \pm 0.30$} \\
\hline & 308 & $2.92 \pm 0.03$ & \\
\hline \multirow{2}{*}{$\begin{array}{l}\text { MCIR } 310 \mathrm{G} \text { del } \\
\text { non-Korean cattle }\end{array}$} & 207 & $2.43 \pm 0.01$ & \multirow{2}{*}{$3.01 \pm 0.15$} \\
\hline & 308 & $2.93 \pm 0.02$ & \\
\hline \multirow{2}{*}{$\begin{array}{l}\text { MCIR } 296 \text { Y SNP } \\
\text { Korean cattle }\end{array}$} & 225 & $2.50 \pm 0.03$ & \multirow{2}{*}{$2.37 \pm 0.28$} \\
\hline & 308 & $2.94 \pm 0.03$ & \\
\hline \multirow{2}{*}{$\begin{array}{l}\text { MCIR } 296 \text { Y SNP } \\
\text { non-Korean cattle }\end{array}$} & 165 & $2.16 \pm 0.02$ & \multirow{2}{*}{$3.97 \pm 0.27$} \\
\hline & 308 & $2.98 \pm 0.02$ & \\
\hline \multirow{2}{*}{$\begin{array}{l}\text { LM2 15-1,2 C } \\
\text { non-Korean cattle }\end{array}$} & 422 & $3.40 \pm 0.02$ & \multirow{2}{*}{$1.81 \pm 0.23$} \\
\hline & 647 & $3.84 \pm 0.02$ & \\
\hline \multirow{2}{*}{$\begin{array}{l}\text { LM2 15-1,2 D } \\
\text { Korean cattle }\end{array}$} & 240 & $2.56 \pm 0.03$ & \multirow{2}{*}{$5.89 \pm 0.29$} \\
\hline & 647 & $3.82 \pm 0.07$ & \\
\hline
\end{tabular}

"Migration time indicates the mean \pm standard deviation $(n=5)$. ${ }^{t} R_{5}=2$ $\left(t_{2}-t_{1}\right)\left(w_{1}+w_{2}\right)$. where $t_{1} t_{2}$. $w_{1}$ and $w_{2}$ are the migration times and peak widths of the adjacent DNA peaks, respectively $(n=5)$.

and accuracy of the amplified AS-PCR products were obtained without any loss of resolution $\left(R_{s}\right)$ for the different SNP markers of the Korean and non-Korean cattle (Table 2). In conclusion. we successfully developed a CE-LIF with voltage programuning method for the determination of the SNP markers of Korean and non-Korean cattle. which correspond to the MCIR gene associated with the coat color. The unique SNP markers of closely related Hanwoo MCIR genes (i.e. MCIR $310 \mathrm{G}$ del, MCIR 296Y SNP. LM215-1.2 C and LM215-1.2 D) were obtained on a fused-silica capillary under voltage programming CE separation conditions within only 4 min. Based on the simultaneous detection of various AS-PCR products. this method can provide the key to the more accurate identification of Korean cattle within several minutes. This assay technique has the potential to be a powerful tool for the fast and simultaneous determination of SNP markers of various cattle breeds with high accuracy

\section{Expenimental Section}

Chemical and reagents. $\mathrm{I} \times$ TBE buffer $(0.089 \mathrm{M}$ Tris. $0.089 \mathrm{M}$ borate $0.002 \mathrm{M}$ EDTA. pH 8.45) was prepared by dissolving a pre-nixed powder (Anrresco ${ }^{\mathbb{E}}$. Solon. OH, USA) in deionized water and further filtered with a $0.2 \mu \mathrm{m}$ membrane-filter (Whatmann ${ }^{E^{\prime}}$, Maidstone, England). Then the buffer solution was photobleached for one day. A dynamic coating gel was made with $1.0 \%(\mathrm{w} / \mathrm{v})$ polyvinylpy rrolidone (PVP, $M_{\mathrm{r}}$ $1.000,000)$ (Polyscience. Warrington. England) in $1 \times$ TBE buffer containing $0.5 \mu \mathrm{g} / \mathrm{mL}$ ethidium bromide ( $\mathrm{EtBr}$. Molecular Probes, Eugene, Oregon, USA). The nuxture was shaken for $\mathrm{l}$ min and left to stand for $2 \mathrm{~h}$ to remove the bubbles. The sieving matrix was prepared by dissolving $0.8 \%(w / v)$ of PEO $\left(M_{4}\right.$ $8.000,000$ ) (Sigma. St. Louis. MO. USA) in I $\times$ TBE buffer together with $0.5 \mu \mathrm{g} / \mathrm{mL}$ EtBr with slow stirring ovemight. The Korean cattle (Jeongeup, Korea) and non-Korean cattle (Michigan. USA) genomic DNA were provided by the Department of Animal Science, Chungbuk National University. The genomic DNA was extracted from the tissue using a QIAamp DNA Micro Kit (Qiagen. Seoul. Korea). The $2 \times$ Multiplex PCR Premix and designed primers used for the antplification of the SNP markers of the Korean and non-Korean cattle were purchased from Solgent (Daejeon, Korea). A 100-bp DNA ladder $(25 \mathrm{ng} / \mu \mathrm{L})$ (Invitrogen. CA. Korea) was used to confirm the length of the PCR products

Genomic DNA preparation. A total of eighteen Korean and non-Korean cattle DNA samples (each nine samples) were obtained from the Chungbuk National University in Korea. The genomic DNA was isolated from the tissues using a QIAamp ${ }^{\sqrt{6} \cdot}$ DNA Micro Kit, according to the manufacturer's instructions. Briefly. $180 \mu \mathrm{L}$ of Buffer ATL was placed in a $1.5 \mathrm{~mL}$ microcentrifuge tube containing less than $10 \mathrm{mg}$ of the tissue sample and equilibrated at room temperature $(15 \cdot 25$ $\left.{ }^{\circ} \mathrm{C}\right) .20 \mu \mathrm{L}$ of Proteinase $\mathrm{K}$ was added. mixed by vortexing for $15 \mathrm{~s}$ and incubated at $56^{\circ} \mathrm{C}$ overnight. Subsequently. $200 \mu \mathrm{L}$ of Buffer AL and $200 \mu \mathrm{L}$ of ethanol ( $96-100 \%$ ) were added and incubated for $5 \mathrm{~min}$ at room temperature. The entire lysate was centrifuged at $8,000 \mathrm{rmm}$ for $\mathrm{I} \mathrm{min}$ and the flow-through discarded. Next. $500 \mu \mathrm{L}$ of Buffer AWI was added and centrifuged at $8,000 \mathrm{rpm}$ for $1 \mathrm{~min}$ and the flow-through discarded. This step was perfonmed one more time and the mixture centrifuged at $14,000 \mathrm{rpm}$ for $3 \mathrm{~min}$ to dry the membrane to the center of which $20-100 \mu \mathrm{L}$ Buffer $\mathrm{AE}$ or distilled water was applied. Finally, the $1.5 \mathrm{~mL}$-microcentrifuge tube of lysate was incubated at room temperature for $1 \mathrm{~min}$ and centrifuged at $14.000 \mathrm{rpm}$ for $1 \mathrm{~min}$. 
Allele-specific PCR sample preparation. The Korean and non-Korean cattle $\mathrm{SNP}$ markers were amplified by allele-specific PCR. MC IR 310G del. MCIR 296Y SNP. LM215-1.2 C and LM215-1,2 D primers were designed by Solgent (Deajeon. Korea) (Table 1). The total volume of the PCR reaction was 40 $\mu \mathrm{L}$. The PCR mixture contained $3 \mu \mathrm{L}$ of $50 \cdot 100$ ng template DNA. $20 \mu \mathrm{L}$ of $2 \times$ Multiples PCR Pre-Mix. $3 \mu \mathrm{L}$ of each of the MCIR 310G del, MCIR 296Y SNP. LM215-1,2 C and LM215-1,2 D primers ( 10 pmole/ $\mu \mathrm{L}$ ). The PCR misture was used for the co-amplification of both specific target DNAs under the same PCR conditions. The PCR was performed in a MyGenie96 Thermal Block (Deajeon. Korea) using the following two temperature protocol: firstly. the temperature protocol of the MCIR $310 \mathrm{G}$ del and MCIR 296Y SNP primers PCR mixture: 15 min pre-denaturation at $95^{\circ} \mathrm{C} .30$ cycles of denaturing at $95^{\circ} \mathrm{C}$ for $20 \mathrm{~s}$, amealing at $60^{\circ} \mathrm{C}$ for $40 \mathrm{~s}, 72^{\circ} \mathrm{C}$ for $1 \mathrm{~min}$ and then 1 cycle of extension at $72^{\circ} \mathrm{C}$ for $1 \mathrm{~min}$. Secondly. the temperature protocol of the LM215-1.2 C and LM215-1.2 $D$ primers $P C R$ mixture: 15 min pre-denaturation at $95^{\circ} \mathrm{C} .35$ cycles of denaturing at $95^{\circ} \mathrm{C}$ for $20 \mathrm{~s}$, annealing at $68^{\circ} \mathrm{C}$ for 1 min and then $1 \mathrm{cycle}$ of extension at $72^{\circ} \mathrm{C}$ for $3 \mathrm{~min}$. The PCR products were analyzed using the CE-LIF system.

Capillary electmphoresis system with LIF detector. The laboratory-assembled CE setup with an LIF detector was described previously. ${ }^{8 ., 702,31}$ Briefly, a $5 \mathrm{~mW}$ He-Ne laser $\left(\lambda_{e, \mathrm{X}}=\right.$ $543.5 \mathrm{~nm}, \lambda_{z \mathrm{mal}}=610 \mathrm{~nm}$ : Melles Griot 05-LGR-193. CA. USA) coupled to a laser-induced fluorescence detector was used as the light source in this work. A Spellman 1000R high-voltage power supply (Spellman ${ }^{*}$. CZE1000R. NY. USA) was used for sample injection and separation in the electrophoresis. A $25 \mathrm{~cm}$ total length $(10 \mathrm{~cm}$ effective length) and $75 \mu \mathrm{m}$ I.D. bare fused-silica capillary (Polymicro Technologies Inc., AZ, USA) was utilized as the separation capillary. The running buffer was composed of $1 \times$ TBE buffer ( $\mathrm{pH} 8.45$ ) with $0.5 \mu \mathrm{g} / \mathrm{mL}$ $\mathrm{EtBr}$. The dynamic coating gel and sieving matrix were sequentially injected hydrodynamically at one end of the capillary using a syringe for $5 \mathrm{~min}$ and $2.5 \mathrm{~min}$, respectively. The sample was injected electrokinetically at $120 \mathrm{~V} / \mathrm{cm}$ for $10 \mathrm{~s}$. The applied electric field strength was in the range of $180-420 \mathrm{~V} / \mathrm{cm}$. After each run, the capillary was reconditioned before subsequent analysis by refilling it with sieving matrix for $2.5 \mathrm{~min}$. The fluorescence signal was collected with a $10 \times$ objective lens (Nikon. Japan) into the photomultiplier module (H7732-10. Hamamatsu, Japan) and transferred to an Autochro data module. Data collection and treatment were performed using an Autochro data system (Young Lin Instnument Co.. Any̦ang. Korea) at $5 \mathrm{~Hz}$.

Voltage programming forfast DNA separation. The voltage programming technique is used as an efficient separation method with a short separation time while maintaining reasonable resolution. ${ }^{11.14}$ Firstly, before the first peak (100 bp DNA) appeared. we applied HCFS of $420 \mathrm{~V} / \mathrm{cm}$ for $1.3 \mathrm{~min}$. Then. for the separation of the 100 to $700 \mathrm{bp}$ DNA fragments. we applied LCFS for $2.9 \mathrm{~min}$. Finally, since the non target DNA fragments do not need to be separated. we applied HCFS for $0.5 \mathrm{~min}$. The voltage programming method was designed in our lab using Labview ${ }^{\text {TM }}$ (version 6.1, National instruments Co., Austin, USA).

Aclnowledgments. This work was supported by a grant (Code 20070501034006) from the BioGreen 21 Program. Rural Development Adninistration, Republic of Korea.

\section{Refeiences}

1. Chung, E. R:- Chung, K. Y. Korean J. Food SCI. 2004, 24, 355.

2. Koh, B.-R.-D. Korean J. Iet. Res. 2005, 45, 351

3. Mengel-From, J.; Borsting, C.; Sanchez, J. J.; Eiberg, H.; Morling. N. Electrophoresis $\mathbf{2 0 0 8}, 29,4780$.

4. Klungland, H.; Văge, D. I.: Gomez-Raya, L.: Adalsteinsson, S.; Lien, S. Hamm. Genonte 1995, 6,636

5. Do, K. T.; Shin, H. Y.; Lee, J. H.; Kim, N. S.; Park, E. W.; Yoon, D. H.; Kim, K. S. J. Amim. Sci. \& Techol 2007, 49, 711

6. Mokrousov, I.; Otten, T.; Filipenko, M.; Vyazovava, A.; Chrapov, E.; Limeschenko, E.; Steklova, L.; Vyshuevskiy, B.; Narvshaya, O. J. Clin. Aficrobiol. 2002, 40,2509 .

7. Guttman, A.; Barta, C.: Szöke, M.; Sasvári-Székely, M.: Kalász, H. J. Chomatogr. A 1998, 828,481.

8. Teon, S.: Eo, S. K.: Kim, Y.: Yoo, D. J.: Kang. S. H. Talanta $\mathbf{2 0 0 7}, 73,415$

9. Jeon, S.: Lee, M. I.: Park, J:- Kang. S. H. J. Chomatogi: B2007. $854,268$.

10. Feng, T.; Arriaga, E. A. Electrophoresis 2008, 29, 475

11. Kang, S. H.; Park, M.; Cho, K. Electrophoresis 2005, $26,3179$.

12. Kumar, K. S.; Lee, M. T.; Park, J.; Kang, S. H. Talanta 2008, 75 , 49.

13. Kumar, K. S.; Lee, H. G.: Yoo, D. T.; Kang, S. H. Bull Korean Chem. Soc $2008,29,153$

14. Kim, Y.-T. Chae, T.S.; Chang, J. K.; Kang, S. H. J. Chromatogr. $12005,1083,179$.

15. Sasazaki, S.; Usui, M.; Mannen, H.; Hiura, C.; Tsuji, S. J. Anim. Sci. 2005, 76, 129

16. Lee, S. S.: Yang. Y. H.: Kang, S. Y.: Oh, W. Y.; Yang. B. S.; Ko, S. B.; Oh, S. T.; Kim. K. I. Amm. Sci. \& Technol $\mathbf{2 0 0 0}, 42,253$.

17. Russo, V.: Fontanesi, L.: Scotti, E.: Tázzoli, M.: DallOlio, S.; Davoli, R. Ital., J. Sci. 2007, 6,257.

18. Baker, D. R. Capillan Electrophoresis, $1^{\text {st }}$ ed.; John Wiley \& Sons Press: New York, U.S.A., 1995 , p 23.

19. Heiger, D. N. High Pelfomance Capillan Electrophoresis, $1^{\text {st }}$ ed.; Hewlett-Packard GmbH Press: Gernany, 1992; p 12.

20. Go, H.: Lee, M.: Li, L.; Kim, K.-S.; Kang, S. H. J. Korean Chem. Soc. $2008,52,630$

21. Kang, S. H.; Jang, S.; Yi, H.-K. J. Korean Chent. Soc. 2000, t9, 537. 